\title{
BRC4Env, a network of Biological Resource Centres for research in environmental and agricultural sciences
}

\author{
Christian Mougin ${ }^{1}$ (D) Emmanuelle Artige ${ }^{2} \cdot$ Frédéric Marchand $^{3} \cdot$ Samuel Mondy $^{4} \cdot$ Céline Ratié $^{5} \cdot$ Nadine Sellier $^{6}$. \\ Philippe Castagnone-Sereno ${ }^{6}$ - Armelle Cœur D'Acier ${ }^{2}$ - Daniel Esmenjaud ${ }^{6}$. Céline Faivre-Primot ${ }^{4}$. \\ Laurent Granjon ${ }^{2}$ • Valérie Hamelet ${ }^{7}$. Frederic Lange ${ }^{8} \cdot$ Sylvie Pagès $^{9} \cdot$ Frédéric Rimet $^{7} \cdot$ Nicolas Ris $^{6}$. \\ Guillaume Sallé ${ }^{10}$
}

Received: 13 March 2018 / Accepted: 5 April 2018 / Published online: 19 April 2018

(C) The Author(s) 2018

\begin{abstract}
The Biological Resource Centre for the Environment BRC4Env is a network of Biological Resource Centres (BRCs) and collections whose leading objectives are to improve the visibility of genetic and biological resources maintained by its BRCs and collections and to facilitate their use by a large research community, from agriculture research to life sciences and environmental sciences. Its added value relies on sharing skills, harmonizing practices, triggering projects in comparative biology, and ultimately proposing a single-entry portal to facilitate access to documented samples, taking into account the partnership policies of research institutions as well as the legal frame which varies with the biological nature of resources. BRC4Env currently includes three BRCs: the Centre for Soil Genetic Resources of the platform GenoSol, in partnership with the European Conservatory of Soil Samples; the Egg Parasitoids Collection (EP-Coll); and the collection of ichthyological samples, Colisa. BRC4Env is also associated to several biological collections: microbial consortia (entomopathogenic bacteria, freshwater microalgae...), terrestrial arthropods, nematodes (plant parasitic, entomopathogenic, animal parasitic...), and small mammals. The BRCs and collections of BRC4Env are involved in partnership with academic scientists, as well as private companies, in the fields of medicinal mining, biocontrol, sustainable agriculture, and additional sectors. Moreover, the staff of the BRCs is involved in many training courses for students from French licence degree to Ph.D, engineers, as well as ongoing training.
\end{abstract}

Keywords Genomic · Genetic · Biological · Resource · Ecosystem · Research · Environment · Agriculture · Platform · Infrastructure

Christian Mougin, Emmanuelle Artige, Frédéric Marchand, Samuel Mondy, Céline Ratié and Nadine Sellier contributed equally to this work.

Responsible editor: Philippe Garrigues

Christian Mougin

christian.mougin@inra.fr

1 UMR ECOSYS, INRA, AgroParisTech, Université Paris-Saclay, 78026 Versailles, France

2 UMR CBGP, INRA, CIRAD, IRD, Montpellier SupAgro, 34988 Montferrier-sur-Lez, France

3 UE U3E, INRA, pôle AFB-INRA Gest'Aqua, 35042 Rennes, France

4 Agroécologie, AgroSup Dijon, INRA, Univ. Bourgogne Franche-Comté, F-21000 Dijon, France

5 US InfoSol, INRA, 45075 Orléans, France
6 INRA, Université Côte d'Azur, CNRS, ISA, 06900 Sophia Antipolis, France

7 UMR CARRTEL, INRA, Université de Savoie, 74203 Thonon-les-Bains, France

8 UMR ECOBIOP, INRA, Université Pau \& Pays Adour, pôle AFB-INRA Gest'Aqua, 64310 Saint-Pee-sur-Nivelle, France

9 UMR DGIMI, INRA, Université de Montpellier, 34095 Montpellier, France

10 UMR ISP, INRA, Université François Rabelais, 37380 Nouzilly, France 


\section{Introduction}

Conserving and ensuring the availability of genetic and biological resources, particularly for the purposes of research, conservation of biodiversity, education, and economic valorization, are today major societal and scientific challenges, mainly faced by Biological Resource Centres (BRCs). In that context, AgroBRC (Agronomic Resources for Research RARe, http://www6.inra.fr/agrobrc-rare/) is a distributed Research Infrastructure connecting French BRCs which are maintaining genetic and biological resources produced and characterized by research on domestic animals, crops and model plant species, wild relatives of domestic species, forestry, micro-organisms relevant for agronomy, food science and environment, soil microbial consortia, and invertebrates and vertebrates of the environment. The BRCs of AgroBRCRARe are grouped in five pillars according to the origin of their resources: animal/crop/forestry/micro-organisms/environment. AgroBRC-RARe is registered on the French national roadmap for Research Infrastructures.

Since late 2015, the pillar "Biological Resource Centre for the Environment" BRC4Env (https://www.brc4env.fr/) is a network of BRCs and collections hosted by several French research institutions INRA (Institut National de la Recherche Agronomique), IRD (Institut de Recherche et Développement), CIRAD (Centre de Coopération Internationale en Recherche Agronomique pour le Développement), and CNRS (Centre National de la Recherche Scientifique), as well as associated to technical and higher education institutions. The leading objective of BRC4Env is to improve the French and European visibility of biological resources maintained by its BRCs and to facilitate their use by a large research community, from agriculture research to life sciences and environmental sciences. Its added value relies on sharing skills, harmonizing practices, triggering projects in comparative biology, and ultimately proposing a single-entry portal to facilitate access to documented samples, taking into account the partnership policies of research institutions as well as the legal frame which varies with the biological nature of resources (i.e., the implementation of the Nagoya protocol).

The biological and/or genomic resources of BRC4Env are sampled from soils, sediments, waters, natural, and agricultural ecosystems... and preserved in organized collections. They include microbial consortia and animal resources (invertebrates and vertebrates). Currently, BRC4Env includes three BRCs: the Centre for Soil Genetic Resources of the platform GenoSol in partnership with the European Conservatory of Soils Samples, the Egg Parasitoids Collection EP-Coll, and the collection of ichthyological samples, Colisa. BRC4Env also comprises other biological collections including microbial consortia (entomopathogenic bacteria, freshwater microalgae...), terrestrial arthropods (insects and mites), nematodes (plant parasitic, entomopathogenic, animal parasitic...), and small mammals (Table 1). These BRCs and collections have collected more than $1,220,000$ samples to date. They possess the structures and equipment to maintain, characterize, and distribute all their biological resources for endusers (Fig. 1).

The network develops interactions with analytical platforms for the characterization of samples (https://www. bre4env.fr/Associated-platforms) in biochemistry: BiochemEnv in Versailles (Cheviron et al. 2018); environmental chemistry: Platinaae in Arras and Bordeaux; genomics: GenoSol; and imaging: DimaCell in Dijon. In Sophia, the BRCs and collection are line with the platform SPIBOC (microscopy, analytical biochemistry, bioinformatics, genomics). BRC4Env can also access to ecosystems through two networks: AnaEE-France (Mougin et al. 2015) and Recotox (https://www.recotox.eu/recotox_eng/, Mougin et al., this Special Issue).

\section{Focus on the BRCs of BRC4Env}

The Centre for Soil Genetic Resources (CSGR, https://www. brc4env.fr/BRCs-and-collections/Environmental-matrices/ GenoSol) of the platform GenoSol provides a national BRC for soils unique in Europe for the storage and conservation of genetic resources (DNA) and making them available to the scientific community. Most of the stored soil samples come from soil survey networks (at national, regional, and landscape scales), environmental research observatories (from INRA, CNRS, and University), long-term experimental sites (within French and European networks), and networks of farms. All these sites are involved in scientific questions concerning the environmental assessment of soil uses and management, as well as the impact of global changes. The platform GenoSol is a strategic tool to supply these sites in the long term and monitor soil biodiversity.

The CSGR of GenoSol is hosted by the research department UMR1347 Agroecologie in Dijon, France. It offers sampling and storage facilities (sampling material, freezers, and dedicated laboratory and rooms) with the possibility to store soils from non-European countries granted by a quarantine agreement. The GenoSol platform has all the laboratory facilities needed for molecular biology studies in the service "Laboratory of Molecular Analysis and Development." Indeed, the CSGR will provide DNA extracted from soil sample rather than soil itself, as soil quantity is limited (ca $50 \mathrm{~g}$ per sample). In consequence, the CSGR of GenoSol needs to routinize and automatize DNA extraction from sample in order to provide good-quality DNA.

GenoSol performs its activities in partnership with the European Conservatory of Soils Samples (CEES, https:// www.brc4env.fr/BRCs-and-collections/Environmentalmatrices/CEES) hosted by the US1106 InfoSol in Orleans, in 
Table 1 Biological Resource Centres and collections of the network BRC4Env

\begin{tabular}{|c|c|c|c|}
\hline $\mathrm{CRB} /$ collections & Samples & Species & Contact \\
\hline Network BRC4Env & & & C. Mougin, UMR ECOSYS \\
\hline \multicolumn{4}{|l|}{ Environmental matrices } \\
\hline $\begin{array}{l}\text { Centre for Soil Genetic } \\
\text { Resources GenoSol } \\
\text { (BRC) }\end{array}$ & 14,000 extracts of soil DNA & Microbial consortia (metagenomes) & $\begin{array}{l}\text { S. Mondy, C. Faivre-Primot, } \\
\text { UMR Agroecologie }\end{array}$ \\
\hline $\begin{array}{l}\text { European Conservatory } \\
\text { of Soils Samples } \\
\text { Microbial consortia }\end{array}$ & 47,000 dry soil samples & / & C. Ratié, US InfoSol \\
\hline Entomopathogenic bacteria & $\begin{array}{l}650 \text { bacterial strains from the } 5 \text { continents } \\
\text { Strains stored in glycerol, or freezed at } \\
-80^{\circ} \mathrm{C} \text { or liquid nitrogen }\end{array}$ & $\begin{array}{l}27 \text { species of Xenorhabdus } \\
4 \text { species of Photorhabdus }\end{array}$ & S. Pagès, UMR DGIMI \\
\hline Freshwater microalgae & $\begin{array}{l}947 \text { strains among diatomophyceae, } \\
\text { chlorophyceae... } \\
486 \text { living cultures }\end{array}$ & 296 taxa (species/varieties) & F Rimet, UMR CARRTEL \\
\hline \multicolumn{4}{|l|}{ Invertebrates } \\
\hline \multicolumn{4}{|l|}{ Arthropodes } \\
\hline $\begin{array}{l}\text { Egg Parasitoids Collection } \\
\text { EP-Coll (BRC) }\end{array}$ & $\begin{array}{l}130 \text { living strains of trichogrammae } \\
2000 \text { samples of DNA }\end{array}$ & $\begin{array}{l}15 \text { living species } \\
25 \text { species as DNA }\end{array}$ & N. Ris, N. Sellier, UMR ISA \\
\hline $\begin{array}{l}\text { Terrestrial Arthropod } \\
\text { Collection }\end{array}$ & $\begin{array}{l}1,000,000 \text { specimens of insects, stored } \\
\text { dry, in ethanol or in slides } \\
10,000 \text { DNA } \\
20,000 \text { specimens of mites in slides, } \\
\text { or in ethanol } \\
1000 \text { samples of DNA }\end{array}$ & $\begin{array}{l}\text { 60,000 species for various groups of high } \\
\text { agronomic importance in Europe } \\
\text { (phytophagous, forest and auxiliary } \\
\text { arthropods): aphids, dipterous leafminers, } \\
\text { (Agromyzidae), thrips, sawflies, chalcidid, } \\
\text { leafrollers, moths and Neuroptera, } \\
\text { Phytoseiidae mites and houses large series } \\
\text { of specimens from the Tropics }\end{array}$ & $\begin{array}{l}\text { E. Artige, A. Cœur-D'Acier, } \\
\text { UMR CBGP }\end{array}$ \\
\hline \multicolumn{4}{|l|}{ Nematodes } \\
\hline Plant-parasitic nematodes & $\begin{array}{l}145 \text { living isolates maintained in } \\
\text { glasshouse on plant (Meloidogyne } \\
\text { spp. and Xiphinema spp.) or in Petri } \\
\text { dishes on fungi (Bursaphelenchus spp.) }\end{array}$ & $\begin{array}{l}80 \text { isolates of } 10 \text { species of Meloidogyne spp. } \\
30 \text { isolates of } 4 \text { species of Xiphinema spp. } \\
35 \text { isolates of } 10 \text { species of } \\
\text { Bursaphelenchus spp. }\end{array}$ & $\begin{array}{l}\text { P. Castagnone-Sereno, D. } \\
\text { Esmenjaud, UMR ISA }\end{array}$ \\
\hline $\begin{array}{l}\text { Entomopathogenic } \\
\text { nematodes }\end{array}$ & $\begin{array}{l}140 \text { living strains stored in dry media } \\
\text { (100 strains of Steinernema and } 40 \\
\text { strains of Heterorhabditis) }\end{array}$ & $\begin{array}{l}26 \text { species of Steinernema } \\
3 \text { species of Heterorhabditis }\end{array}$ & S. Pagès, UMR DGIMI \\
\hline Animal parasitic nematodes & $\begin{array}{l}9435 \text { samples including male and female } \\
\text { adults and infective larvae }\end{array}$ & $\begin{array}{l}31 \text { parasitic species of } 11 \\
\text { host species }\end{array}$ & G. Sallé, UMR ISP \\
\hline \multicolumn{4}{|l|}{ Vertebrates } \\
\hline Small Mammals collection & $\begin{array}{l}81,000 \text { samples } \\
2250 \text { whole specimens (skins, skulls } \\
10,000 \text { skulls, } 4000 \text { skins } \\
50,000 \text { tissues in ethanol } \\
2000 \text { DNA extracts } \\
5500 \text { buffered RNA } \\
500 \text { cell cultures } \\
300 \text { chromosome preparations } \\
5000 \text { nematodes endoparasites in ethanol } \\
1500 \text { ectoparasites (fleas, ticks, mites) } \\
\text { in ethanol }\end{array}$ & $\begin{array}{l}\text { Cricetidae, Arvicolinae subfamily (France: } \\
\text { Microtus, Arvicola, Myodes), Muridae } \\
\text { mostly Murinae (Europe, Africa, Asia: } \\
\text { Apodemus, Mus) and Gerbillinae (West } \\
\text { and North); some specimen of Sciuridae, } \\
\text { Nesomyidae (Dendromurinae) and } \\
\text { Dipodidae. } \\
\text { Soricomorpha mostly Soricidae and } \\
\text { Crocidurinae (Sorex, Neomys, Suncus) } \\
\text { Some Erinaceomorpha (Erinaceidae, } \\
\text { Erinaceinae) } \\
\text { Some Chriroptera }\end{array}$ & $\begin{array}{l}\text { E. Artige, L/ Granjon, } \\
\text { UMR CBGP }\end{array}$ \\
\hline $\begin{array}{l}\text { Collection of } \\
\text { ichthyological samples } \\
\text { Colisa (BRC) }\end{array}$ & $\begin{array}{l}200,000 \text { scales, pieces of fin, otoliths } \\
\text { and caps of freshwater fish and lamprey }\end{array}$ & $\begin{array}{l}26 \text { species collected in whole } \\
\text { France during } 46 \text { years }\end{array}$ & $\begin{array}{l}\text { F. Marchand, UE U3E } \\
\text { Valérie Hamelet, UMR } \\
\text { CARRTEL } \\
\text { Frederic Lange, UMR } \\
\text { ECOBIOP }\end{array}$ \\
\hline
\end{tabular}

the frame of the French Network of Measurement of Soil Quality (RMQS, Réseau de Mesures de la Qualité des Sols). The CEES stores an archive of French soils collected within the national soil survey and monitoring programs coordinated by the French Soils Scientific Interest Group (GIS Sol). This collective infrastructure is also supporting French and 

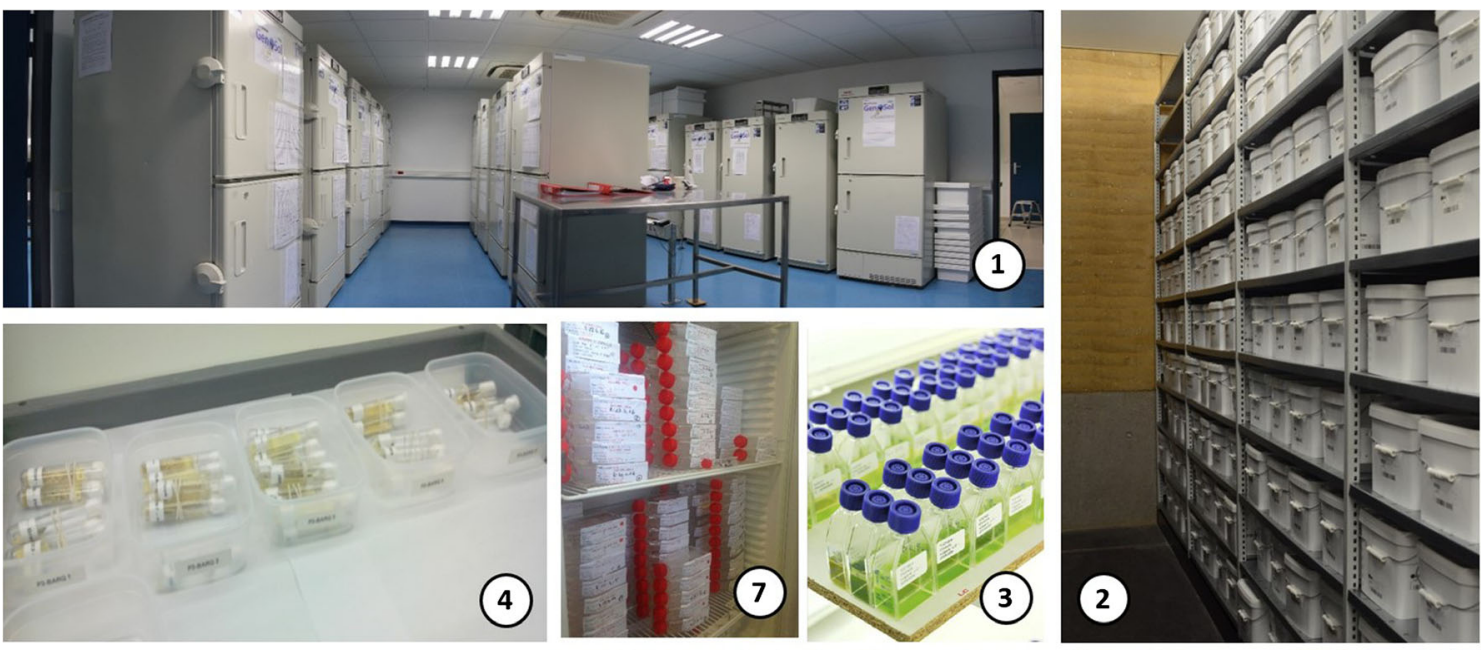
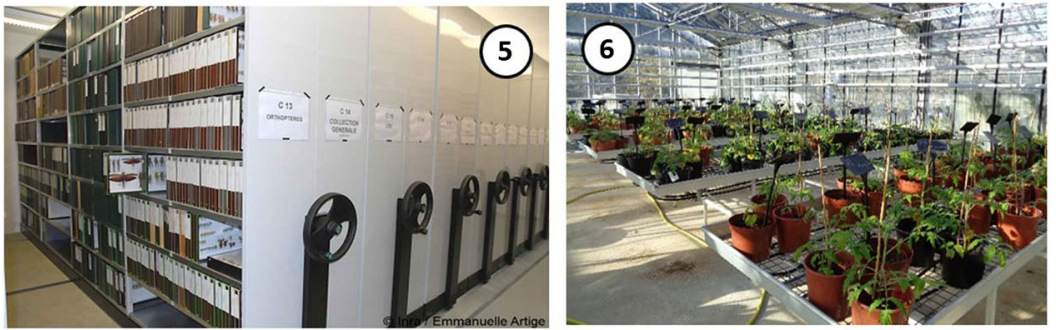

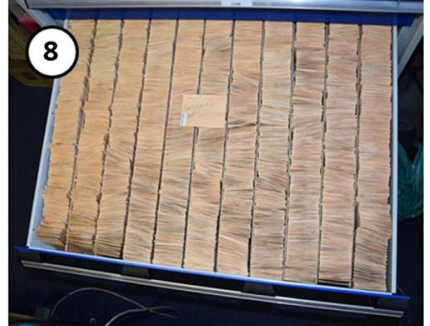

Collection, (5) Terrestrial arthropod and small mammals collection, (6) Plant-parasitic nematodes, (7) Entomopathogenic nematodes, (8) Collection of ichthyological samples Colisa

criteria; (v) the optimization of sampling, rearing, and management methods; and (vi) the optimization of phenotyping methods.

The BRC is deposited at the UMR1355 Institut Sophia AgroBiotech (ISA) in Sophia Antipolis, France. ISA is a research laboratory which benefits of an original collective scientific infrastructure PlantBIOs (Plants Biostimulation and Biocontrol facilities and expertise (https://www6.paca.inra.fr/ institut-sophia-agrobiotech/Infrastructure-PlantBIOs)), with greenhouses and controlled environment chambers for carrying out in vitro and in situ experiments, with official agreement for the manipulation of quarantine insects and nematodes, and all the laboratory needed for morphological and molecular biology studies.

For the BRC EP-Coll, the main technological/ methodological developments rely on integrative taxonomy combining molecular and morphological information as well as crossing experiment, improvement of sampling through various methods (sentinel eggs with various eggs, sampling of natural egg clutches, etc.), and thermal biology including the development of a prototype for the evaluation of some key parameters.

The historical collection of fish scales and tissues (Colisa, https://www.brc4env.fr/BRCs-and-collections/Vertebrates/ Colisa) results from the merging of historical samples collected by three INRA units (U3E in Rennes, ECOBIOP 
in Saint-Pée-sur-Nivelle, and CARRTEL in Thonon-lesBains) and by FBA (French national Agency for Biodiversity) as part of the AFB-INRA Pole "Gest'aqua." These samples come from long-term monitoring and research activities conducted by these units and from a national catch declaration scheme (angling and professional fishery).

Beyond age and growth, these samples, carrying DNA, allow genetic characterization of individuals or population. Using microchemistry, these samples allow to characterize the trophic status and the environmental conditions of life of these animals. The conservation of these tissues allows investigating historical changes (global and local) that have occurred.

\section{BRC4Env as a relevant support for research programs}

The network BRC4Env and its BRCs and collections implement a quality management according to the INRA Quality Framework v2 for optimized functioning, continual improvement, and stakeholder satisfaction. They plan to move to national (NF S 96-900) or international (ISO 9001:2015) certification in the next 2 years. Numerous BRCs and collections ensure the traceability and planning of their animation activities using the software AQ-tools developed by CIRAD (http:// golo.cirad.fr). The network BRC4Env, the CSGR of GenoSol, EP-Coll, and Colisa have been labelled as BRCs by the French organism IBiSA.

The BRCs follow the rules of good scientific and ethical practices, policies, and regulations. BRC4Env is committed to provide an operational support to its members regarding the implementation of the Access and Benefit Sharing and the Nagoya protocol, and the staff of the BRC follows training accordingly. Several BRCs benefit from a French approval of quarantine facilities, for handling and experiments on soils and organisms from non-continental European territories and non-European countries.

Thus, the BRCs and collections of BRC4Env are involved in partnership with academic scientists, as well as with private companies, in the fields of medicinal mining, biocontrol, sustainable agriculture, and additional sectors. Since their creation, the BRCs of BRC4Env have been involved in about 140 research contracts as partners of academic laboratories, and 30 are ongoing during the year 2016, at French or international scales. The projects are led by scientists belonging to the departments hosting the BRCs, or by external partners.

Examples or research projects involving BRC4Env collections are presented below.

1) The environmental assessment of soil uses and management, as well as the impact of global changes on soil biodiversity, positioning BRC4Env as a strategic tool to supply the long-term sites for observation and experimentation. In that respect, the Centre for Soil Genetic Resources of the platform GenoSol collects, stores, and characterizes soil samples from the different sites of the SOERE PRO (Systèmes d'observation et d'expérimentation au long terme pour la recherche en Environnement - Produits résiduaires Organiques), by providing temporal set of samples to scientists (Obriot et al. 2016). In addition, the project CammiSole aims at understanding the role of soil microbial biodiversity in the provision of services of plant production, nutrient cycling, and carbon sequestration, in relationships to global changes in soils from Madagascar (Razanamalala et al. 2018). The project ECOMIC-RMQS (Réseau de Mesures de la Qualité des Sols) aims at better defining and understanding the processes governing the microbial biodiversity of soils, by a better estimation and characterization of the "beta" diversity of the communities (species turnover along an environmental gradient). The RMQS1 network offers 2200 sampled soils and covers the whole French territory (Ranjard et al. 2013; Terrat et al. 2017; Horrigue et al. 2016). The RMQS2 program is ongoing (Swiderski et al. 2017).

2) The freshwater microalgae culture collection of the BRC4Env (Thonon Culture Collection) holds more than 900 strains (Diatom, Chlorophyceae, Cyanobacteria...). Microalgae and especially Diatoms are known to be excellent indicators of aquatic ecosystem pollution (Rimet 2012). This collection enabled to develop a reference barcoding library R-Syst:diatom (Rimet et al. 2016) which enabled to set up new tools based on DNA metabarcoding to assess river and lake quality which are more efficient than classical microscope-based methods (e.g., Keck et al. 2017). Such methods are currently standardized at European level.

3) Trichograms of the BRC EP-Coll are relevant biological models for eco-evolutionary investigations and constitute a reservoir of candidate strains (species/populations/genotypes) for biocontrol (Marchand et al. 2017; Martinez-Rodriguez et al. 2016). The ANR program TRIPTIC (Trichogramma pour la protection des cultures: Pangénomique, Traits d'histoire de vIe et Capacités d'établissement) aims at characterizing the inter- and intra-specific diversity of the Trichogramma species at several levels of investigation (genome, individual, population (Dumbardon et al. 2018) and even community) with explicit outputs for both basic (phylogeny, systematics, comparative analysis; Ris et al. 2016), applied (potential strains of biocontrol agents), and regulation (native versus exotic biodiversity) issues. Complementary programs such as the FP7/PEOPLE/IAPP COLBICS aim at more readily exploiting these inter- and intra-specific diversities for the development of new biological control agents (Declaration of Invention "DI RV 17 0076: Genetic improvement of T. brassicae"). 
4) The Terrestrial Arthropod Collection of BRC4Env is the basis of various collaborative national and international research programs related to plant health or biodiversity, combining molecular, morphological, and chorological information. This collection, managed by the CBGP (Artige 2017), is used for several molecular barcoding programs (Rasplus and Loomans 2017).

The key action Sys3D (Systematics for the Detection, the Diagnosis and the iDentification; whose goal is to create fast and reliable tools for plant diagnosis) of the INRA metaprogram $\mathrm{SMaCH}$ (Sustainable Management of Crop Health, 20102020) relies on a part of this Arthropods Collection: sequenced specimens, studied morphologically, preserved with their DNA for traceability purposes (Laval and Streito 2017).

The reference collection of European quarantine Arthropods, an outcome of the European project FP7/QBOL/Q-Bank (Rasplus and Loomans 2017) is also hosted at CBGP. Informative genes from species selected in EU Directive and EPPO lists are DNA barcoded from vouchered specimens. Methodological outcomes of this program are a non-destructive extraction technique, an amplification protocol using primers multiplexing, a bioinformatics pipeline for sequences validation, and a structured database with a web interface. This website is automatically updated using the DBMS (Database Managing System) used for the Terrestrial Arthropods collection.

New species have recently been described using specimens from this collection. Examples include a phytophagous mite (Arabuli et al. 2016), a seed pest beetle (Mouttet et al. 2016), or a new species of darkling beetle (Soldati et al. 2016). The collection is also used by research programs aiming to estimate the relative weights of ecological factors and geographical isolation on the speciation processes within several groups of Arthropods (Meseguer et al. 2015; Migeon 2015).

In return, this collection is regularly enriched by specimens collected via these research programs.

5) The samples of the collection Colisa, carrying DNA, allow genetic characterization of wild fish individuals or population. Via microchemistry, these samples allow to characterize the trophic status and the environmental conditions of life of these animals (Rougemont et al. 2016). The conservation of these tissues allows investigating historical changes (global and local) that have occurred. The project "Temporal evolution of genetic parameters in Lake Geneva's arctic charr population" assess the spatial and temporal evolution of genetic parameters charr population (Savary et al. 2017). Atlantic Aquatic Resource Conservation (AARC) was a collaborative effort between several European institutions, and combined high-quality science with practical help for rivers around the Atlantic coast. This was achieved by working at the appropriate scale to the problem in hand, using a variety of different approaches; including conservation genetics (historical tissue collection), river restoration, aquaculture, and educational approaches across the European partners (Quéméré et al. 2016).

6) The Plant-parasitic Nematodes Collection of BRC4Env has been the support of various collaborative European research programs. For example, the pinewood nematode collection has been instrumental in the achievement of some objectives of the FP7/EU-project REPHRAME (Development of improved methods for detection, control and eradication of pine wood nematode in support of EU Plant Health Policy). Together with additional field sampling, these biological resources have been used to characterize the genetic diversity of nematode populations from both the native and the invaded areas, and to infer the worldwide routes of invasion of the parasite (Vieira et al. 2014; Mallez et al. 2015; Ciordia et al. 2016). These new data are of direct practical importance for the implementation of efficient phytosanitary measures for quarantine regulation.

7) The collection of animal parasitic nematodes has been established 30 years ago. It has originally been dedicated to ruminant trichostrongylid to delineate the genetic basis of anthelmintic resistance (Silvestre and Humbert 2002; Neveu et al. 2007). Recent surveys provided additional samples for equine parasite species (Sallé et al. 2017) that was also used for work on anthelmintic drug receptors (Courtot et al. 2015). The breadth of its sampling area has recently been used for a project dedicated to characterize the global diversity of Haemonchus contortus populations, one of the most deadly livestock parasitic nematodes (Marie-Curie FP7 COFUND People Programme, grant agreement 609398). The molt of this collection towards a more formal BRC has been recently initiated.

8) The CBGP Small Mammal Collection, including specimens (skins and/or skulls) and their corresponding samples (i.e., organ parts, blood or cells in ethanol, various buffers, or cryopreserved), and the Small Mammal Database gathering all the associated information have been the support of a number of studies over the last years. Among others, we may cite the description of the invasion of Senegal by the house mouse (Dalecky et al. 2015) based on the compilation of data on commensal rodents in Senegal over the period 1983-2014 in the frame of the JCJC ANR programme "ENEMI"; a review on camouflage in a set of species of gerbil species based on analyses of their skin reflectance (Boratyński et al. 2017); various studies on the phylogeny of supraspecific groups (Ndiaye et al. 2012, 2016...) or intraspecific phylogeography (Hima et al. 2011; Dobigny et al. 2013); and a growing amount of works highlighting the role of small mammals as reservoirs of a number of 
zoonotic pathogens potentially transmissible to humans (e.g., Dobigny et al. 2015 for Leptospira, Tatard et al. 2017 for Trypanosoma, Diagne et al. 2017a, b for bacteria and viruses in West Africa). This collection and associated database have represented the basic materials for an updated synthesis on West African rodents (Granjon and Duplantier 2009), and also serve as depository of information for the "West African Observatory on small mammals as indicators of environmental changes" (ObsMiCE), relying on a network of observation sites all over West Africa, and which is currently supported by IRD and OSU Pytheas fundings.

More than 200 scientific publications have been produced by the BRCs of the network since their creation. Book chapters, presentations at conferences, and technical notes have been also produced. Moreover, the staff of the BRCs is involved in many training courses for students from French license to Ph.D degree, engineers, as well as ongoing training. They welcome also numerous students for internships every year.

\section{The next steps of BRC4Env}

BRC4Env builds on existing facilities, equipment, and human resources of its BRCs, collections, and hosting laboratories. The vision of BRC4Env is the long-term collaboration and common development of strategies, best practices, and standards related to the use and preservation of environmental resources for basic and applied research in the field of environment and agronomy. Achieving fully transparent collection access procedures, securing financial sustainability and ensuring conformity to regulation form critical objectives for BRC4Env. To reach these objectives, BRC4Env will also benefit from the know-how developed by the other pillars of AgroBRC-RARe, which have been established for a longer time.

In the context of the project "Implementing ABS regulations by agronomic BRCs in the national infrastructure RARe" (ABS4BRCs), BRCs and collections of BRC4Env will determine the legal status of their accessions and consequences for their introduction and distribution, regarding the Access and Benefit Sharing as well as French and European policies. A case study based on soil samples will be developed during the project, because these resources are not well characterized at the time of sampling in terms of taxonomy.

The main objective of BRC4Env is to develop the Information System of the network, currently constituted by shared tools and distributed services among BRCs, by making these tools interoperable and relevant regarding the Nagoya policy. A specificity of BRC4Env is the hosting of living collections of invertebrates. The Information System must provide and share information concerning sampling, rearing, phenotyping and molecular data, and barcoding. Here, we plan to set the following requirements: (i) centralization and standardization of metadata concerning the resources, (ii) secure storage and confidentiality by controlled access, (iii) tools to perform queries (in partnership with applications to be developed by AgroBRC-RARe). A common database for registering the projects hosted by the BRCs of the network will be developed.

The Information System of BRC4Env will offer shared information dedicated to the resources hosted by its BRCs. It will also promote and contribute to make easier the access, storage, archiving of datasets, and their subsequent valorization, and provide to end-users access to the productions of the network (publications, catalogues...) by subscription to News and RSS feed. Experience gained in other pillars of AgroBRC-RARe in these fields will be used in order to optimize the functional specificities of our IS and to select the most relevant technical solution.

BRC4Env shares two main other objectives in the next future.

- Internal practice harmonization. Considering the diversity of BRCs and collections, the network will encourage practice harmonization for improved management and enhanced traceability of its activities within its BRCs and make available a comprehensive set of harmonized procedures. One main objective is the introduction (if necessary), the development, and the support for a common processbased quality management system for continual improvement and stakeholder satisfaction. Taken together, these actions will facilitate the sharing of experience and the identification of best practices within the BRCs and collections of the network. Sharing experience will then make possible to define a common policy for BRC and collections functioning, charters for sample and data access, relationships between BRCs and private partners...

- Valorization of the activities of the BRCs. The network will produce scientific and perspective papers (in openaccess journals), illustrating the research questions that a better and beneficial coordination between BRCs can help to tackle, as well as the scientific and technical support they can provide to end-users. The network promotes also the production by the BRCs and collections of technical papers valorizing their expertise and know-how. It will also produce and support an action plan for attending national and relevant international conferences and workshops to increase its national and international visibility.

\section{Conclusion}

BRC4Enc is a network structuring the BRCs dedicated to environmental resources in France. It is currently seeking for 
similar networks of BRCs in Europe and worldwide to be a French component of international networks. Today, environmental resources are mainly taken into account in environmental specimen banking. BRC4Env can offer a frame to host samples and collections specifically addressing ecotoxicological issues.

Acknowledgments The network BRC4Env thanks the Research Infrastructure AgroBRC-RARe, the French National Institute for Agricultural Research (INRA), and the GIS IBiSA for supporting its activities (BRC4Env, GenoSol, EP-Coll, and Colisa benefit of the IBiSA label). GenoSol and Biochem-Env are services of the "Investment d'Avenir" infrastructure AnaEE-France, overseen by the French National Research Agency (ANR) (ANR-11-INBS-0001).

Open Access This article is distributed under the terms of the Creative Commons Attribution 4.0 International License (http:// creativecommons.org/licenses/by/4.0/), which permits unrestricted use, distribution, and reproduction in any medium, provided you give appropriate credit to the original author(s) and the source, provide a link to the Creative Commons license, and indicate if changes were made.

\section{References}

Arabuli T, Cobanoglu S, Auger P (2016) Panonychus from Georgia: survey, taxonomical status and redescription of $P$. hadzhibejliae (Reck, 1947) (Acari, Tetranychidae). Zootaxa 4114(4):464-476

Artige E (2017) Gestion d'une collection entomologique : une infrastructure dédiée au CBGP. Les Cahiers Techniques de l'Inra, Numéro spécial Entomologie appliquée, pp. 13-24. https://www6.inra.fr/ cahier_des_techniques/Les-Cahiers-parus/Les-N-Speciaux/ Entomologie/chap1-ns-Entomologie-2017

Boratyński Z, Brito JC, Campos JC, Cunha JL, Granjon L, Mappes T, Ndiaye A, Rzebik-Kowalska B, Serén N (2017) Repeated evolution of camouflage in speciose desert rodents. Sci Rep 7:3522

Cheviron N, Grondin V, Mougin C (2018) Biochem-Env: a platform of biochemistry for research in environmental and agricultural sciences. Environ Sci Pollut Res 25:6154-6157

Ciordia S, Arcos SC, Roberston L, González MR, Mena MC, Zamora P, Vieira P, Sousa E, Abrantes I, Mota M, Castagnone-Sereno P, Navas A (2016) Protein markers of Bursaphelenchus xylophilus Steiner \& Buhrer, 1934 (Nickle, 1970) populations using quantitative proteomics and character compatibility. Proteomics 16:1006-1014

Courtot E, Charvet CL, Beech RN, Harmache A, Wolstenholme AJ, Holden-Dye L, O'Connor V, Peineau N, Woods DJ, Neveu C (2015) Functional characterization of a novel class of morantelsensitive acetylcholine receptors in nematodes. PLoS Pathog 11(12):e1005267

Dalecky A, Bâ K, Piry S, Lippens C, Diagne CA, Kane M, Sow A, Diallo M, Niang Y, Konečný A, Sarr N, Artige E, Charbonnel N, Granjon L, Duplantier JM, Brouat C (2015) Range expansion of the invasive house mouse Mus musculus domesticus in Senegal, West Africa: a synthesis of trapping data over three decades, 1983-2014. Mammal Rev 45:176-190

Diagne C, Galan M, Tamisier L, d'Ambrosio J, Dalecky A, Bâ K, Kane M, Niang Y, Diallo M, Sow A, Gauthier P, Tatard C, Loiseau A, Piry S, Sembène M, Cosson JF, Charbonnel N, Brouat C (2017a) Ecological and sanitary impacts of bacterial communities associated to biological invasions in African commensal rodent communities. Sci Rep 7:14995
Diagne CA, Charbonnel N, Henttonen H, Sironen T, Brouat C (2017b) Serological survey of zoonotic viruses in invasive and native commensal rodents in Senegal, West Africa. Vector Borne Zoonotic Dis 17:730-733

Dobigny G, Tatard C, Gauthier P, Bâ K, Duplantier JM, Granjon L, Kergoat GJ (2013) Mitochondrial and nuclear genes-based phylogeography of Arvicanthis niloticus (Murinae) and subSaharan open habitats Pleistocene history. PLoS One 8(11):e77815

Dobigny G, Garba M, Tatard C, Loiseau A, Galan M, Kadaouré I, Rossi JP, Picardeau M, Bertherat E (2015) Urban market gardening and rodent-borne pathogenic Leptospira in arid zones: a case study in Niamey, Niger. PLoS Trop Negl Dis 9:e004097

Dumbardon-Martial T, Lucas P-D, Warot Sylvie, Ris N, Groussier G (2018). Inventaires des espèces du genre Trichogramma sur cucurbitacées cultivées et plantes associées en Martinique en vue du développement de méthodes de lutte biologique, Bull Soc Entomol Fr, submitted.

Granjon L, Duplantier JM (2009) Les rongeurs de l'Afrique sahélosoudanienne. Editions de l'IRD (Collection Faune et Flore tropicales), Marseille, p 216

Hima K, Thiam M, Catalan J, Gauthier P, Duplantier JM, Piry S, Sembène M, Britton-Davidian J, Granjon L, Dobigny G (2011) Extensive Robertsonian polymorphismin the African rodent Gerbillus nigeriae: geographic aspects and meiotic data. J Zool 284:276-285

Horrigue W, Dequiedt S, Chemidlin Prévost-Bouré N, Jolivet C, Saby NPA, Arrouays D, Bispo A, Maron P-A, Ranjard L (2016) Predictive model of soil molecular microbial biomass. Ecol Indic 64:203-211

Keck F, Vasselon V, Tapolczai K, Rimet F, Bouchez A (2017) Freshwater biomonitoring in the Information Age. Front Ecol Environ 15(5): 266-274

Laval V, Streito JC (2017). SM. A. CH. Séminaire SMaCH - 10 novembre 2017. Du diagnostic visuel au séquençage : Sys3D un outil de diagnostic intégratif pour la tomate et la vigne. https://inradam-front-resources-cdn.brainsonic.com/ressources/afile/4166497343f-resource-diagnostic-bioagresseurs-tomate-vigne-smach.pdf

Mallez S, Castagnone C, Espada M, Vieira P, Eisenback JD, Harrell M, Mota M, Aikawa T, Akiba M, Kosaka H, Castagnone-Sereno P, Guillemaud T (2015) Worldwide invasion routes of the pinewood nematode: what can we infer from population genetics analyses? Biol Invasions 17:1199-1213

Marchand A, Sellier N, Warot S, Ion-Scotta M, Ris N, GroussierBout G (2017) Formalisation d'un centre de ressources biologiques dédié aux parasitoïdes oophages: CRB Ep-Coll. Cahier des Techniques de l'INRA, Numéro spécial Entomologie appliquée, pp 49-58, https://www6.inra.fr/ cahier_des_techniques/Les-Cahiers-parus/Les-N-Speciaux/ Entomologie/chap1-ns-Entomologie-2017

Martinez-Rodriguez P, Berger C, Groussier Bout G, Dumbardon-Martial T, Lepilleur T, Maignet P, Malausa T, Ris N, Sanchez-Martin V, Seguret J, Vergès V, Warot S, Zaviezo T, Morel-Journel T (2016). Exploring and exploiting intraspecific diversity in the genus Trichogramma. XXV International Congress of Entomology, Orlando, USA, September 24-30

Meseguer AS, Coeur d'Acier A, Genson G, Jousselin E (2015) Unravelling the historical biogeography and diversification dynamics of a highly diverse conifer-feeding aphid genus. J Biogeogr 42(8):1482-1492

Migeon A (2015) The Jean Gutierrez spider mite collection. Zookeys 489:15-24

Mougin C, Azam D, Caquet T, Cheviron N, Dequiedt S, Le Galliard JF, Guillaume O, Houot S, Lacroix G, Lafolie F, Maron PA, Michniewicz R, Pichot C, Ranjard L, Roy J, Zeller B, Clobert J, Chanzy A (2015) A coordinated set of ecosystem research platforms 
open to international research in ecotoxicology, AnaEE-France. Environ Sci Pollut Res 22(20):16215-16228

Mouttet R, Moreto M, Delobel A, Kergoat GJ (2016) Une bruche nouvelle pour la France : Bruchidius terrenus (Sharp, 1886) (Coleoptera : Chrysomelidae : Bruchinae). Bull Soc Entomol Fr 121:87-89

Ndiaye A, Bâ K, Aniskin V, Benazzou T, Chevret P, Konecny A, Sembène M, Tatard C, Kergoat GJ, Granjon L (2012) Evolutionary systematics and biogeography of endemic gerbils (Rodentia, Muridae) from Morocco: an integrative approach. Zool Scr 41:11-28

Ndiaye A, Chevret P, Dobigny G, Granjon L (2016) Evolutionary systematics and biogeography of the arid habitat-adapted rodent genus Gerbillus (Rodentia, Muridae): a mostly Plio-Pleistocene African history. J Zool Syst Evol Res 54:299-317

Neveu C, Charvet C, Fauvin A, Cortet J, Castagnone-Sereno P, Cabaret J (2007) Identification of levamisole resistance markers in the parasitic nematode Haemonchus contortus using a cDNA-AFLP approach. Parasitology 134(8):1105-1110

Obriot F, Stauffer M, Goubard Y, Cheviron N, Peres G, Eden M, Revallier A, Vieuble-Gonod L, Houot S (2016) Multi-criteria indices to evaluate the effects of repeated organic amendment applications on soil and crop quality. Agric Ecosyst Environ 232:165-178

Quéméré E, Baglinière J-L, Roussel J-M, Evanno G, McGinnity P, Launey S (2016) Seascape and its effect on migratory life-history strategy influences gene flow among coastal brown trout (Salmo trutta) populations in the English Channel. J Biogeogr 43:498-509

Ranjard L, Dequiedt S, Prevost-Bouré NC, Thioulouse J, Saby N, Lelievre M, Maron P-A, Morin F, Bispo A, Jolivet C, Arrouays D, Lemanceau P (2013) Turnover of soil bacterial diversity driven by wide-scale environmental heterogeneity. Nat Commun 4:1434

Rasplus JY, Loomans AJM (2017) Q-bank Arthropods database [en ligne]. Mise à jour en 2017. http://www.q-bank.eu/arthropods/

Razanamalala K, Razafimbelo T, Maron P-A, Ranjard L, Chemidlin N, Lelievre M, Dequiedt S, Ramaroson VH, Marsden C, Becquer T, Trap J, Blanchart E, Bernard L (2018) Soil microbial diversity drives the priming effect along climate gradients: a case study in Madagascar. ISME J 12(2):451-462. https://doi.org/10.1038/ismej. 2017.178

Rimet F (2012) Recent views on river pollution and diatoms. Hydrobiologia 683:1-24

Rimet F, Chaumeil P, Keck F, Kermarrec L, Vasselon V, Kahlert M, Franc A, Bouchez A (2016) R-Syst:diatom: an open-access and curated barcode database for diatoms and freshwater monitoring. Database 2016:1-21

Ris N, Martinez-Rodriguez P, Cruaud A, Malausa T, Rasplus JY, Groussier Bout G, Warot S, Seguret J (2016) Disentangling taxonomic issues and reproductive isolation patterns in complexes of cryptic species in the genus Trichogramma. XXV International Congress of Entomology, Orlando, USA, September 24-30

Rougemont Q, Roux C, Neuenschwander S, Goudet J, Launey S, Evanno G (2016) Reconstructing the demographic history of divergence between European river and brook lampreys using approximate Bayesian computations. PeerJ 4:e1910

Sallé G, Cortet J, Bois I, Dubès C, Guyot-Sionest Q, Larrieu C, Landrin V, Majorel G, Wittreck S, Woringer E, Couroucé A, Guillot J, Jacquiet P, Guégnard F, Blanchard A, Leblonde A (2017) Risk factor analysis of equine strongyle resistance to anthelmintics. Int $\mathrm{J}$ Parasitol Drugs Drug Resist 7(3):407-415

Savary R, Dufresnes C, Champigneulle A, Caudron A, Dubey S, Perrin N, Fumagalli L (2017) Stocking activities for the Arctic charr in Lake Geneva: genetic effects in space and time. Ecol Evol 7: 5201-5211

Silvestre A, Humbert JF (2002) Diversity of benzimidazole-resistance alleles in populations of small ruminant parasites. Int J Parasitol 32(7):921-928

Soldati L, Condamine FL, Clamens AL, Mogia M \& Kergoat GJ (2016). The Tenebrionidae (Insecta, Coleoptera) of Mount Wilhelm and Wanang, with description of a new species and a preliminary phylogeny of Stenochiinae. In: Robillard T., Legendre F., Villemant C. \& Leponce M., eds. Insects of Mount Wilhelm, Papua New Guinea, Mémoires du Muséum national d'Histoire naturelle 209, Paris: Muséum national d'Histoire naturelle, pp. 1-31

Swiderski C, Saby N, Boulonne L, Jolivet C, Cousin I (2017) Méthodologie d'élaboration du plan d'échantillonnage de la deuxième campagne du Réseau de Mesures de la Qualité des Sols de France par intégration multi-critères: capacité à détecter une évolution temporelle, évaluation du réservoir en eau utilisable et contraintes logistiques.Etude et Gestion des Sols, 24:83-98. https://www.afes.fr/wpcontent/uploads/2017/09/2406-83-98swiderski.pdf

Tatard C, Garba M, Gauthier P, Hima K, Artige E, Dossou HJ, Gagaré S, Genson G, Truc P, Dobigny G (2017) Rodent-borne Trypanosoma from cities and villages of Niger and Nigeria: a special role for the invasive genus Rattus? Acta Trop 17:151-158

Terrat S, Horrigue W, Dequietd S, Saby NPA, Lelièvre M, Nowak V, Tripied J, Régnier T, Jolivet C, Arrouays D, Wincker P, Cruaud C, Karimi B, Bispo A, Maron P-A, Prévost-Bouré NC, Ranjard L (2017) Mapping and predictive variations of soil bacterial richness across France. PLoS One 12:e0186766

Vieira P, Castagnone C, Mallez S, Espada M, Navas A, Mota M, Castagnone-Sereno P (2014) Sequence variability of the MspI satellite DNA family of the pinewood nematode Bursaphelenchus xylophilus at different geographic scales. Mol Phylogenet Evol 70: $120-129$ 